\title{
BSR versus Climate Change and Slides
}

\author{
U. Tinivella, M. Giustiniani, and D. Accettella \\ Istituto Nazionale di Oceanografia e di Geofisica Sperimentale, 34010 Sgonico, Italy \\ Correspondence should be addressed to U. Tinivella, utinivella@ogs.trieste.it
}

Received 29 March 2011; Accepted 7 June 2011

Academic Editor: Xuewei Liu

Copyright ( 12011 U. Tinivella et al. This is an open access article distributed under the Creative Commons Attribution License, which permits unrestricted use, distribution, and reproduction in any medium, provided the original work is properly cited.

\begin{abstract}
We investigate the relationship between climate change and hydrate stability in two peri-Antarctic areas: Antarctic Peninsula and South Chile. We consider these areas because the polar and subpolar areas are the most sensitive about global change. The zone, where the methane can be easily released by hydrate melting, is the shallow water, that is, in proximity of the intersection between the BSR and the sea bottom. In order to simulate the effect of climate change on hydrate stability, we consider the following seven scenarios for both areas: present environmental condition; sea bottom temperature increase/decrease of $1^{\circ} \mathrm{C}$ water depth increase/decrease of $100 \mathrm{~m}$; sea bottom temperature and water depth increase/decrease of $1^{\circ} \mathrm{C}$ and $100 \mathrm{~m}$, respectively. On the basis of our result, we can draw the conclusion that the modeling is a useful tool to understand the effect of the climate change on hydrate stability. Moreover, in these areas where the sea bottom temperature is influenced by temperature increase, slides could be easily triggered by hydrate dissociation.
\end{abstract}

\section{Introduction}

Submarine slides are global phenomena that can occur on slopes that may be considerably less inclined than their terrestrial equivalents due to the presence of excess water $[1,2]$. They can displace huge amounts of material over great distances. For example, the Storegga slide of Norway had a total run-out distance of about $800 \mathrm{~km}$, with a total displaced volume of sediments estimated to be in the order of $5500 \mathrm{~km}^{3}$ [3]. Slope failures occur when the downslope driving forces due to gravity and other factors exceed the resisting forces that are inherited from the sediment strength. During the last decades, a debate was started regarding the relationship among gas hydrate, climate change, and slope stability. In fact, gas hydrates represent a significant geohazard that is of immediate importance to near and offshore developments. Human activities and installations in regions of gas hydrate occurrence must take into account the presence of gas hydrate and deal with the consequences of its presence [4].

The hydrate stability zone in marine environments is a function of the water depth, the seafloor temperature and the geothermal gradient. Any changes to the temperature and/or pressure, both at the surface and in the area adjacent to the hydrate, affect the thickness of the stability zone.
Although temperature and pressure are the main controls in the formation of gas hydrates and the thickness of the hydrate stability zone, other factors such as gas chemistry and gas availability will also alter the thickness and location of the hydrate stability zone [5]. Dissociation of hydrate may trigger the sudden release of large amounts of methane through the ocean into the atmosphere, leading to accelerated climate warming. Hydrate dissociation and gas release in the atmosphere have been proposed as a significant mechanism to explain the rapid and significant climate change during the Palaeocene-Eocene Thermal Maximum [6-9]. This hypothesis has been challenged by different studies, which suggest that methane from dissociating hydrate may never have reached the atmosphere $[10,11]$. Alternatively it has been proposed that methane release may follow, rather than lead, climate change [12].

The association between gas hydrates and submarine slope failure has been widely documented (e.g., [2, 3, 1316]). As is well known, gas hydrates have been found to be a significant constituent of seafloor sediment in many continental shelf-slope environments around the world $[17,18]$. There are many examples of a possible connection between gas hydrates and submarine slope failures. Kvenvolden [9, 10] summarized slope failures on the continental slope and rise of the west coast of Africa, on the US Atlantic continental 
slope, in the fjords of British Columbia, and on the Alaskan Beaufort Sea continental margin. Several researchers have performed in-depth analyses of the Norwegian continental margin [19-23], and all have suggested that gas hydrates may have triggered one or more large submarine slides in this area. The other famous examples of coincident gas hydrate distribution and slope failure include the Cape Fear slide on the continental slope and of the rise southeast of Cape Fear, North Carolina [15], the Humboldt slide zone near the Mendocino triple junction on the Northern California continental margin [14], and the submarine slope failure in offshore Fiordland [2].

In the last years, several authors (i.e., [22-24]) have investigated the relationship between the gas hydrate dissociation and the increase of pore fluid pressure below the bottom simulating reflector (BSR), which is the seismic indication of the base of the gas hydrate stability zone. In fact, dissociation of gas hydrates at the BSR, in response to a change in the physical environment (i.e., temperature and/or pressure regime), can liberate excess gas and elevate the local pore fluid pressure in the sediment $[24,25]$. The increase in pore fluid pressure has the effect of decreasing the effective normal stress on any assumed failure surface, so that less shear stress is required to initiate failure. Whether free gas liberation by gas hydrate dissociation can singularly cause a slide, rather than just being a contributing load or the final trigger, is dependent on various factors. These include rate of dissociation, sediment permeability, depth below sea level, and depth below the seafloor [26].

For decomposing gas hydrates to be a widespread cause of slope failure, three criteria must be met [28]: (1) gas hydrates must not only be present, but must be widespread as well; (2) slides must have originated in areas that are within the gas hydrate phase boundaries; (3) soils of low permeability must be common at the base of the hydrate zones (to permit the buildup of excess pore pressure that could lead to unstable slopes during sea-level falls).

In this paper, we focus our attention on the slides that occur in area where the BSR is shallow and, consequently, in the area where the hydrate stability is influenced by climate change, that is, temperature and pressure changes. In order to quantify the effects of gas hydrate dissociation, a numerical analysis has been undertaken in two areas: Antarctic Peninsula and South Chile (Figure 1). The first area is chosen because the polar regions are more sensitive to climate change. In fact, the climate change signals are particularly amplified in transition zones, such as the periAntarctic regions [29]. On the other hand, the high amount of gas hydrate present in the South Chile plays an important geohazard related to intense seismicity affecting the region $[30,31]$ and shallow BSR locally present [32]. In this contest, we plan to study the relationship between the shallow hydrate/BSR depth and the pressure/temperature changes.

\section{The Study Areas}

2.1. Antarctic Peninsula. A strong BSR was identified on multichannel seismic reflection and ocean bottom seismometer (OBS) data acquired during the Austral summers 1989/1990

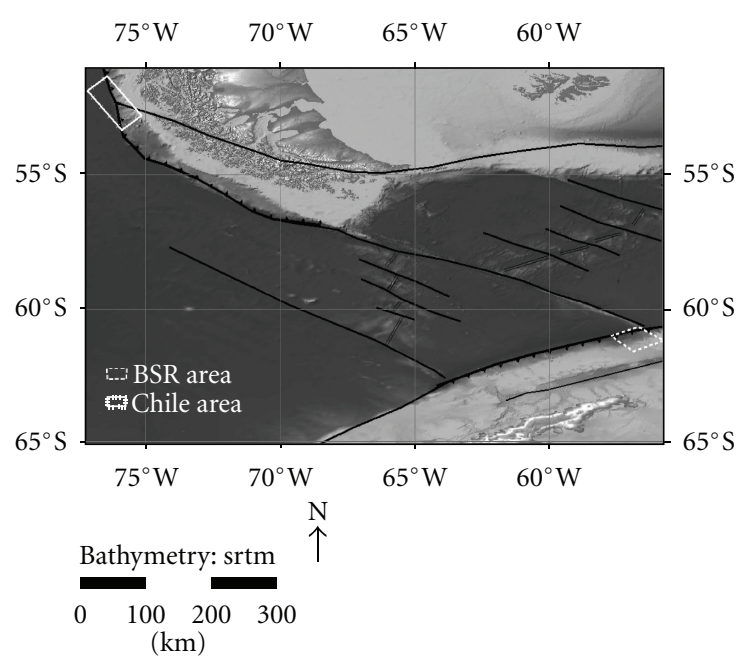

(a)

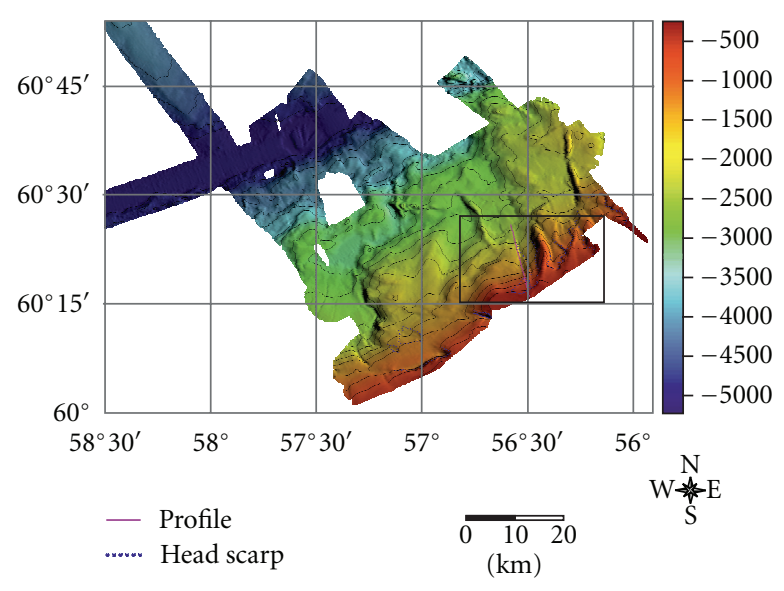

(b)

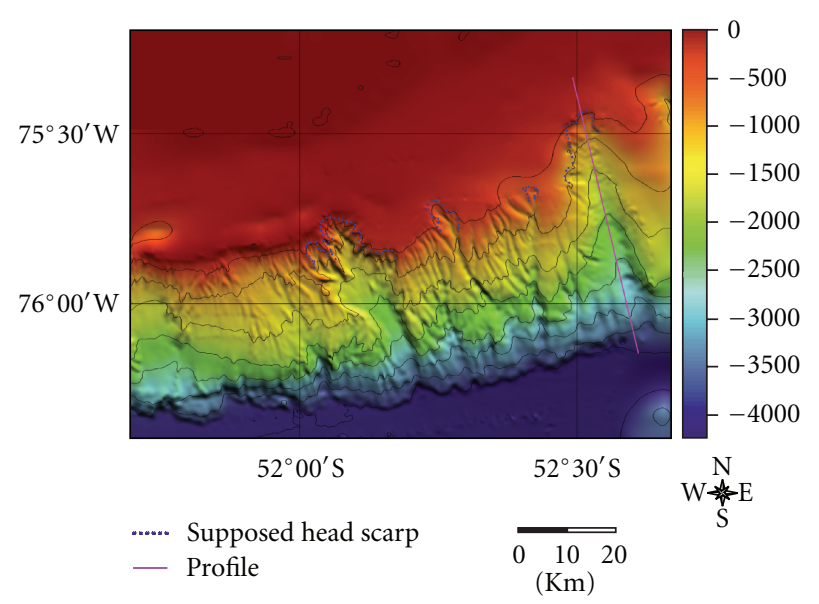

(c)

FIgURE 1: (a) Location map of investigated areas. (b) Multibeam map of the Antarctic area. The pink solid line represents the analyzed profile, while the black block represents the analyzed area reported in Figure 2. (c) Multibeam map of the Chile area. The pink solid line represents the analyzed profile. 


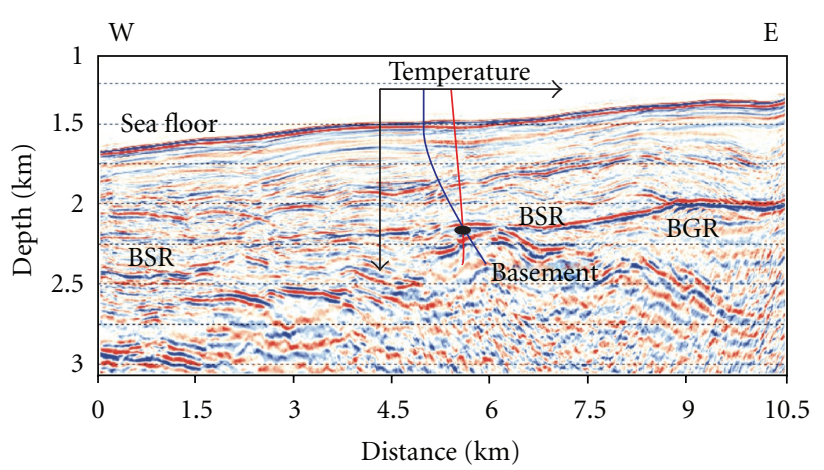

FIgURE 2: Example of prestack depth migrated section from Antarctic Peninsula with a clear BSR (austral summer 1996/1997, line IT213). See location map and details in [27]. BGR: base of free gas reflector. Insert: blue line: geothermal curve. Red line in the insert: gas hydrate stability curve. The intersection between the two curves indicates the BSR depth.

[33], 1996/1997 [27] on the South Shetland margin. Example of the seismic data acquired in this area with a clear BSR was reported in Figure 2. In the prestack depth migrated section the presence of the base of the free gas reflector (BGR; [33]) is clearly detected. To better characterize the area where the BSR is very strong and continuous, another cruise was carried out to acquire detailed bathymetric data ( $12 \mathrm{kHz}$ was the acoustic frequency used), subbottom profile data, two gravity cores, and seismic data with a short hydrophone streamer $(600 \mathrm{~m})$ during the Austral summer 2003/2004 [29]. The multibeam bathymetric data, collected using a Reson multibeam echo sounding system (Reson SeaBat 8150), cover an area of about $4,500 \mathrm{~km}^{2}[29,34]$. The data were calibrated using water column velocity profiles, reconstructed from conductivity-temperature-density measurements (CTD) acquired in four representative sites. The new bathymetry map was generated in the form of a shaded digital elevation model, using the processing software PDS2000 and based on a cell grid size of $100 \times 100 \mathrm{~m}$ (Figure 1). The bathymetric map of the study area provides evidence of mud volcanoes, collapse troughs, and recent slides [29].

The geothermal gradient of the area was estimated analyzing the seismic data, in particular comparing the BSR depth extracted by seismic data analysis and the theoretical BSR depth evaluated considering different geothermal gradient [34]. The analysis indicated that the regional geothermal gradient is $38^{\circ} \mathrm{C} / \mathrm{km}$, considering the sea bottom temperature equal to $0.4^{\circ} \mathrm{C}$, as indicated by OBS [27] and CTD data [34].

2.2. South Chile. The second study area is located along the south Chilean margin on the continental slope (Figure 1). BSRs have been detected during several geophysical cruises. In particular, BSR has been recognized along the accretionary prism by several authors [32, 35-40]. Unfortunately, in this area data from Global Multi-Resolution Topography compilation [41] were available (http://media.marinegeo.org/category/bathymetry), which contain multibeam data form NBP0602 Project (Simrad EM120; Figure 1). Consequently, the resolution is about $600 \mathrm{~m} /$ node, and it is difficult to recognize evidences of slides at relative shallow depth. In the literature, no information about slide related to gas hydrate in the southern Chilean margin can be found. Moreover, on the basis of bathymetric data, we focused our attention on a slide located in the northern part of the investigated area.

The geothermal gradient is very variable along this margin (see, e.g., [32]). For this reason, we considered a constant geothermal gradient equal to $38^{\circ} \mathrm{C} / \mathrm{km}$ as in Antarctic Peninsula. The sea bottom temperature was considered equal to $2.2^{\circ} \mathrm{C}$, as reported in [42].

\section{The Modeling}

Our objective is to verify if the climate change (i.e., sea level and bottom temperature changes) can be responsible of slides because of gas hydrate dissociation. As is well known, the most crucial zone is the area where there is the intersection of the base of the gas hydrate stability zone with the seabed. This area is affected by a bottom-water temperature increase more than the deeper parts on the hydrate stability zone [19]. In the first condition, gas hydrates are close to their stability limit and will respond quickly to the anticipated warming of the polar region because thermal diffusion times through any overlying sediment are short. Recent models have shown that shallow and cold deposit can be very unstable and release significant quantities of methane under the influence of as little as $1^{\circ} \mathrm{C}$ of seafloor temperature increases [43].

For this reason, we model the effect of climate change on the intersection between the base of the gas hydrate stability field and the seafloor. By using bathymetric data, sea bottom temperature, geothermal gradient and considering that the natural gas is methane, we evaluate the theoretical BSR [34]. It was calculated considering the intersection between the geothermal curve (evaluated from sea bottom temperature and geothermal gradient) and the hydrate stability curve, considering the Sloan formula [5]. Figure 2 indicates the geothermal (blue line in the insert) and the gas hydrate stability (red line in the insert) curves, and their intersection is in correspondence to the BSR depth. The bathymetric data are translated in pressure considering the average water density equal to $1046 \mathrm{~kg} / \mathrm{m}^{3}$, as reported in the literature [44].

In order to simulate the effect of climate change on BSR depth, we consider small temperature variation (equal to $1^{\circ} \mathrm{C}$ ) in order to verify how slight climate change can influence hydrate stability, as suggested recently by several authors (i.e., [43]). Regarding the sea level change, several models have suggested that the sea level dropped of almost $100 \mathrm{~m}$ during the Last Glacial Maximum [45]. For this reason, we adopt this sea level variation in our modeling. On the base of these considerations, we consider the following seven scenarios for both areas: (S0) present environmental condition from measurements; (S1) sea bottom temperature increase of $1^{\circ} \mathrm{C}$ with respect to the present temperature (interglacial period scenario); (S2) sea bottom temperature 
decrease of $1^{\circ} \mathrm{C}$ with respect to the present temperature (glacial period scenario); (S3) water depth increase of $100 \mathrm{~m}$ with respect to the present bathymetry (interglacial period scenario); (S4) water depth decrease of $100 \mathrm{~m}$ with respect to the present bathymetry (glacial period scenario); (S5) sea bottom temperature and water depth increases of $1^{\circ} \mathrm{C}$ and $100 \mathrm{~m}$, respectively, with respect to the present environmental conditions (interglacial period scenario); (S6) sea bottom temperature and water depth decreases of $1^{\circ} \mathrm{C}$ and $100 \mathrm{~m}$, respectively with respect to the present environmental conditions (glacial period scenario).

In Antarctic Peninsula, the seismic BSR depth is affected by an error of about $5 \%$, while the bathymetric data present an error of about $1.5 \%$ [34]. Consequently, we consider that the theoretical BSR, evaluated by using the geothermal gradient extracted from seismic and bathymetric data, is affected by an error of about $6.5 \%$. So, we consider that the BSR crosses the seafloor if the difference between the bathymetry and the theoretical BSR depth is less than the bathymetry multiplied by $6.5 \%$. Because not more detailed information is available in the South Chile, we suppose the error considered in the first dataset for coherence.

The results of the modeling are shown in Figure 3 for both analyzed areas. The grids representing each scenario are reported with different colors superimposed on multibeam data. In order to understand the effect of climate change on the slope stability, we evaluate the relationship between the considered scenarios and the identified slides, indicated by solid line in Figure 1.

In Figure 4, we show the results of our modeling for both analyzed profiles. The solid line indicates the present situation, that is, the intersection between the BSR and the seafloor. The dashed lines represent the scenarios (S2, S3), in which the hydrate is more stable. On the contrary, the dissociation of the gas hydrate is represented by dotted lines for scenarios S1, S4, and S6. Scenario S5 affects very weakly the depth of the intersection between the base of the hydrate stability and the seafloor.

\section{Discussion and Conclusions}

Our modeling clearly shows the relationship between the gas hydrate and the slope stability. In fact, the lines in Figure 4, representing the intersection between the gas hydrate stability and the seafloor for each scenario, are located in proximity of the main head scarp (see Figure 1). This result confirms the hypothesis that the hydrate can influence the slope stability causing important slides. It is important to underline that direct measurements of sedimentary sequence are not available; so, consideration about the age of the slides and the climate change is just a speculation.

As already mentioned, we extract profiles, which cross two slides, to better evaluate the effect of climate change on the intersection between the hydrate stability and the seafloor. Note that the results of the two models are in agreement. Note that the two datasets have a different resolution and, for this reason, we perform a qualitative analysis of the model results.

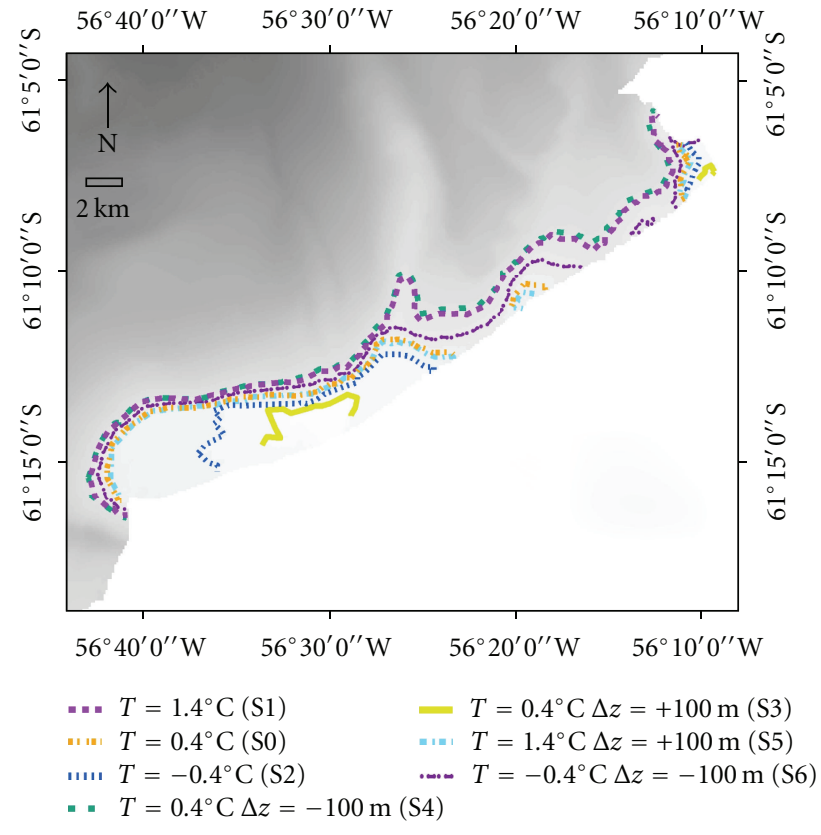

(a)

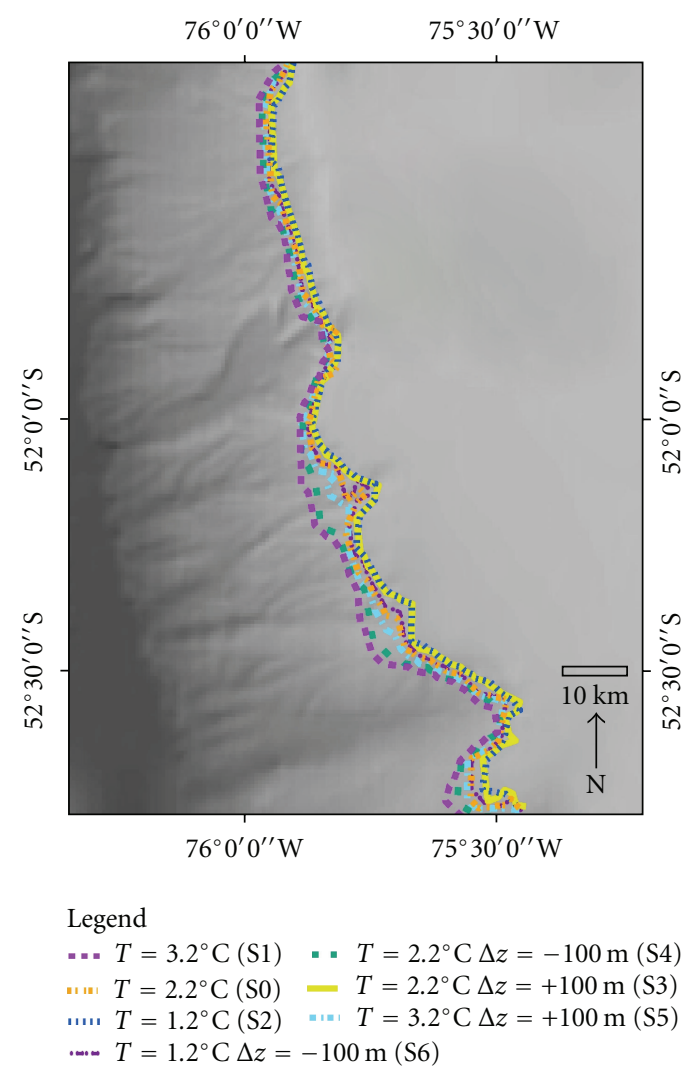

(b)

FIgURE 3: The colored lines indicate the intersection between the seafloor and the BSR in Antarctic (a) and the Chile (b) areas. The different scenarios are indicated according to the text. 


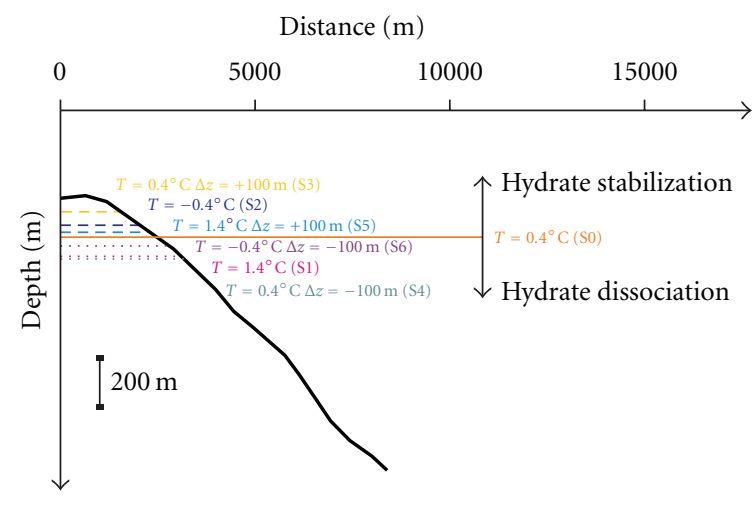

(a)

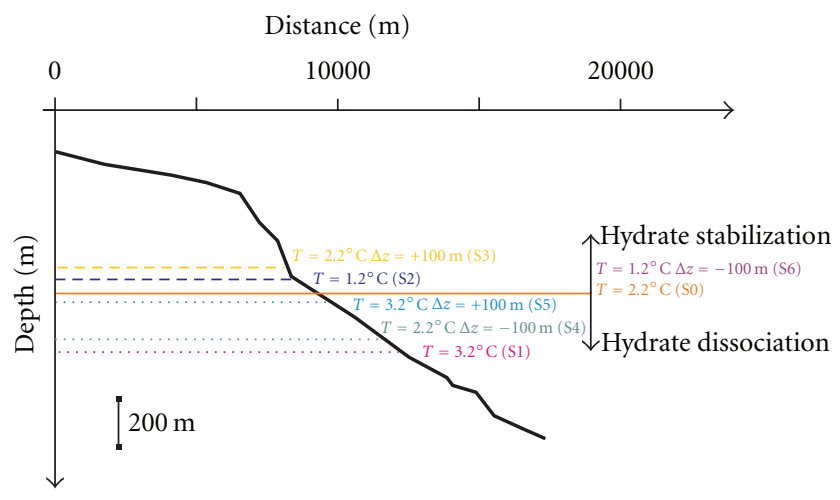

(b)

FIGURE 4: The colored lines indicate the intersection between the seafloor and the BSR along the analyzed profiles in Antarctic (a) and the Chile (b) areas. The different scenarios are indicated according to the text.

Let us consider the glacial period, in which we have the decrease of temperature and decrease of pressure. At the beginning, we suppose just a decrease of the temperature (scenario S2), and the result indicates a positive feedback. On the contrary, when the cooling produces a pressure decrease (scenarios S4 and S6), the negative feedback is observed. In this case, gas is released in the seawater, and consequently in the atmosphere, reducing the cooling.

In the interglacial period, the first effect is the temperature increase (scenario S1). As expected, the modeling indicates gas hydrate dissociation (positive feedback). So, the methane released can reach the atmosphere, contributing to the global warming. If we consider a case in which the seabottom temperature is not affected by global warming and the water depth increases (scenario S3), the feedback is negative, that is, the hydrate is stable. If we consider the joint effect of temperature and pressure increase, the effect of hydrate stability is negligible. Resuming, the hydrate influences the slope stability and the climate change during the interglacial period only at the beginning of the warming and only if sea bottom is influenced by temperature variation.

In conclusion, our modeling points out the strong relationship between gas hydrate presence and climate change. So, it is very important to perform a modeling in the areas where gas hydrate is present in order to simulate the effect of climate change on hydrate and slope stabilities. It is clear that, in these areas, where the sea bottom temperature is influenced by temperature increase, slides could be easily triggered by hydrate dissociation.

\section{References}

[1] M. A. Hampton, H. J. Lee, and J. Locat, "Submarine landslides," Reviews of Geophysics, vol. 34, no. 1, pp. 33-59, 1996.

[2] G. J. Crutchley, A. R. Gorman, and M. Fohrmann, "Investigation of the role of gas hydrates in continental slope stability west of Fiordland, New Zealand," New Zealand Journal of Geology and Geophysics, vol. 50, no. 4, pp. 357-364, 2007.

[3] S. Bouriak, M. Vanneste, and A. Saoutkine, "Inferred gas hydrates and clay diapirs near the Storegga Slide on the southern edge of the Vøring Plateau, offshore Norway," Marine Geology, vol. 163, no. 1-4, pp. 125-148, 2000.

[4] K. A. Kvenvolden, "Gas hydrate and humans," Annals of the New York Academy of Sciences, vol. 912, pp. 17-22, 2000.

[5] E. D. Sloan Jr., Clathrate Hydrates of Natural Gases, Marcel Dekker, New York, NY, USA, 1998.

[6] D. E. Archer and B. Buffett, "Time-dependent response of the global ocean clathrate reservoir to climatic and anthropogenic forcing," Geochemistry, Geophysics, Geosystems, vol. 6, no. 3, Article ID Q03002, 2005.

[7] G. R. Dickens, "The blast in the past," Nature, vol. 401, pp. 752-753, 1999.

[8] J. P. Kennett, K. G. Cannariato, I. L. Hendy, and R. J. Behl, "Carbon isotopic evidence for methane hydrate instability during quaternary interstadials," Science, vol. 288, no. 5463, pp. 128-133, 2000.

[9] K. A. Kvenvolden, "Gas hydrates—geological perspective and global change," Reviews of Geophysics, vol. 31, no. 2, pp. 173187, 1993.

[10] K. A. Kvenvolden, "Potential effects of gas hydrate on human welfare," Proceedings of the National Academy of Sciences of the United States of America, vol. 96, no. 7, pp. 3420-3426, 1999.

[11] T. Sowers, "Late quaternary atmospheric $\mathrm{CH}_{4}$ isotope record suggests marine clathrates are stable," Science, vol. 311, no. 5762, pp. 838-840, 2006.

[12] E. G. Nisbet, "Have sudden large releases of methane from geological reservoirs occurred since the last glacial maximum, and could such releases occur again?" Philosophical Transactions of the Royal Society, vol. 360, no. 1793, pp. 581-607, 2002.

[13] G. B. Carpenter, "Coincident sediment slump/clathrate complexes on the U.S. atlantic continental slope," Geo-Marine Letters, vol. 1, no. 1, pp. 29-32, 1981.

[14] M. E. Field and J. H. J. Barber, "A submarine landslide associated with shallow seafloor gas and gas hydrates off Northern California," in Submarine Landslides: Selected Studies in the U.S. Exclusive Economic Zone, W. C. Schwab, H. J. Jee, and D. C. Twichell, Eds., pp. 971-972, U.S. Geological Survey, Reston, Va, USA, 1993.

[15] P. Popenoe, E. A. Schmuck, and W. P. Dillon, "The cape fear landslide: slope failure associated with salt diapirism and gas hydrate decomposition," in Submarine Landslides-Selected Studies in the U.S. Exclusive Economic Zone, W. C. Schwab, H. J. Lee, and D. C. Twichell, Eds., pp. 40-53, U.S. Geological Survey, Reston, Va, USA, 2002.

[16] M. F. Nixon and J. L. H. Grozic, "A simple model for submarine slope stability analysis with gas hydrates," Norwegian Journal of Geology, vol. 86, no. 3, pp. 309-316, 2006. 
[17] K. A. Kvenvolden, "Methane hydrates and global climate," Global Biogeochemical Cycles, vol. 2, pp. 221-229, 1988.

[18] B. A. Buffett, "Clathrate hydrates," Annual Review of Earth and Planetary Sciences, vol. 28, pp. 477-507, 2000.

[19] J. Mienert, M. Vanneste, S. Bünz, K. Andreassen, H. Haflidason, and H. P. Sejrup, "Ocean warming and gas hydrate stability on the mid-norwegian margin at the Storegga Slide," Marine and Petroleum Geology, vol. 22, no. 1-2, pp. 233-244, 2005.

[20] W.-Y. Jung and P. R. Vogt, "Thermal models for post-glacial evolution of the gas hydrate stability zone: Storegga Slide, Norwegian Margin," in Proceedings of the AAPG Annual Meeting, Naval Research Laboratory, Salt Lake City, Utah, USA, 2004.

[21] P. R. Vogt and W.-Y. Jung, "Holocene mass wasting on upper non-Polar continental slopes-due to post-glacial ocean warming and hydrate dissociation?" Geophysical Research Letters, vol. 29, no. 9, pp. 55-1-55-4, 2002.

[22] N. Sultan, P. Cochonat, M. Canals et al., "Triggering mechanisms of slope instability processes and sediment failures on continental margins: a geotechnical approach," Marine Geology, vol. 213, no. 1-4, pp. 291-321, 2004.

[23] N. Sultan, P. Cochonat, J. P. Foucher, and J. Mienert, "Effect of gas hydrates melting on seafloor slope instability," Marine Geology, vol. 213, no. 1-4, pp. 379-401, 2004.

[24] M. J. Hornbach, D. M. Saffer, and W. S. Holbrook, "Critically pressured free-gas reservoirs below gas-hydrate provinces," Nature, vol. 427, pp. 142-144, 2004.

[25] M. J. Hornbach, W. S. Holbrook, A. R. Gorman, K. L. Hackwith, D. Lizarralde, and I. Pecher, "Direct seismic detection of methane hydrate on the Blake Ridge," Geophysics, vol. 68, no. 1, pp. 92-100, 2003.

[26] W. Xu and L. N. Germanovich, "Excess pore pressure resulting from methane hydrate dissociation in marine sediments: a theoretical approach," Journal of Geophysical Research, vol. 111, Article ID B01104, 12 pages, 2006.

[27] U. Tinivella and F. Accaino, "Compressional velocity structure and Poisson's ratio in marine sediments with gas hydrate and free gas by inversion of reflected and refracted seismic data (South Shetland Islands, Antarctica)," Marine Geology, vol. 164, no. 1-2, pp. 13-27, 2000.

[28] W. P. Dillon and M. D. Max, "Oceanic gas hydrates," in Natural Gas Hydrate in Oceanic and Polar Environments, M. Max, Ed., chapter 6, pp. 61-76, Kluwer Academic Publishers, Dodrecht, The Netherlands, 2000.

[29] U. Tinivella, F. Accaino, and B. D. Vedova, "Gas hydrates and active mud volcanism on the South Shetland continental margin, Antarctic Peninsula," Geo-Marine Letters, vol. 28, no. 2, pp. 97-106, 2007.

[30] I. Grevemeyer, N. Kaul, and J. L. Diaz-Naveas, "Geothermal evidence for fluid flow through the gas hydrate stability field off Central Chile-transient flow related to large subduction zone earthquakes?" Geophysical Journal International, vol. 166, no. 1, pp. 461-468, 2006.

[31] D. Lange, The south chilean subduction zone between $41^{\circ}$ and $43.5^{\circ} \mathrm{S}$ : seismicity, structure and state of stress, Dissertation, University of Potsdam, Potsdam, Germany, 2008.

[32] I. V. Cordero, U. Tinivella, F. Accaino, M. F. Loreto, F. Fanucci, and C. Reichert, "Analyses of bottom simulating reflections offshore Arauco and Coyhaique (Chile)," Geo-Marine Letters, vol. 30, no. 3-4, pp. 271-281, 2009.

[33] U. Tinivella, E. Lodolo, A. Camerlenghi, and G. Boehm, "Seismic tomography study of a bottom simulating reflector off the South Shetland Islands (Antarctica)," Geological Society, vol. 137, pp. 141-151, 1998.

[34] M. Giustiniani, D. Accettella, U. Tinivella, M. F. Loreto, and F. Accaino, "Geographic information system: an application to gas hydrate reservoir," Advances in Geosciences, vol. 18, pp. 213-222, 2008.

[35] N. L. Bangs, D. S. Sawyer, and X. Golovchenko, "Free gas at the base of the gas hydrate zone in the vicinity of the Chile triple junction," Geology, vol. 21, no. 10, pp. 905-908, 1993.

[36] K. M. Brown, N. L. Bangs, P. N. Froelich, and K. A. Kvenvolden, "The nature, distribution, and origin of gas hydrate in the Chile triple junction region," Earth and Planetary Science Letters, vol. 139, no. 3-4, pp. 471-483, 1996.

[37] J. Diaz-Naveas, Sediment subduction and accretion at the Chilean convergent margin between 35' and 40'S, Dissertation zur Etlangung des Doktorgrades, Christian-AlbrechtsUniversitat zu Kiel, Kiel, Germany, 1999.

[38] E. G. Morales, "Methane hydrates in the Chilean continental margin," Electronic Journal of Biotechnology, vol. 6, no. 2, pp. 3-7, 2003.

[39] I. Grevemeyer, J. L. Diaz-Naveaz, C. R. Ranero, and H. W. Villenger, "Heat flow over the decensing nazca plate in central Chile, $32^{\circ} \mathrm{S}$ to $41^{\circ} \mathrm{S}$ : observations from ODP leg 202 and the occurrence of natural gas hydrates," Earth and Planetary Science Letters, vol. 213, pp. 285-298, 2003.

[40] I. V. Cordero, U. Tinivella, F. Accaino, M. F. Loreto, and F. Fanucci, "Thermal state and concentration of gas hydrate and free gas of coyhaique, Chilean margin $\left(44^{\circ} 30^{\prime} S\right)$," Marine and Petroleum Geology, vol. 27, no. 5, pp. 1148-1156, 2010.

[41] W. B. F. Ryan, S. M. Carbotte, J. O. Coplan et al., "Global multi-resolution topography synthesis," Geochemistry, Geophysics, Geosystems, vol. 10, no. 3, Article ID Q03014, 2009.

[42] I. Grevemeyer and H. Villinger, "Gas hydrate stability and the assessment of heat flow through continental margins," Geophysical Journal International, vol. 145, no. 3, pp. 647-660, 2001.

[43] M. T. Reagan and G. J. Moridis, "Dynamic response of oceanic hydrate deposits to ocean temperature change," Journal of Geophysical Research, vol. 113, Article ID C12023, 21 pages, 2008.

[44] A. Giorgetti, A. Crise, R. Laterza, L. Perini, M. Rebesco, and A. Camerlenghi, "Water masses and bottom boundary layer dynamics above a sediment drift of the Antarctic Peninsula pacific margin," Antarctic Science, vol. 15, no. 4, pp. 537-546, 2003.

[45] M. J. Bentley, "Volume of Antarctic ice at the last glacial maximum, and its impact on global sea level change," Quaternary Science Reviews, vol. 18, no. 14, pp. 1569-1595, 1999. 

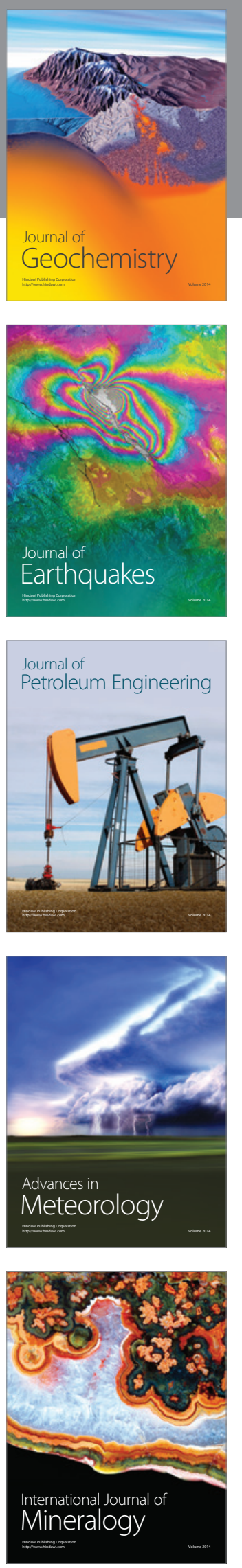
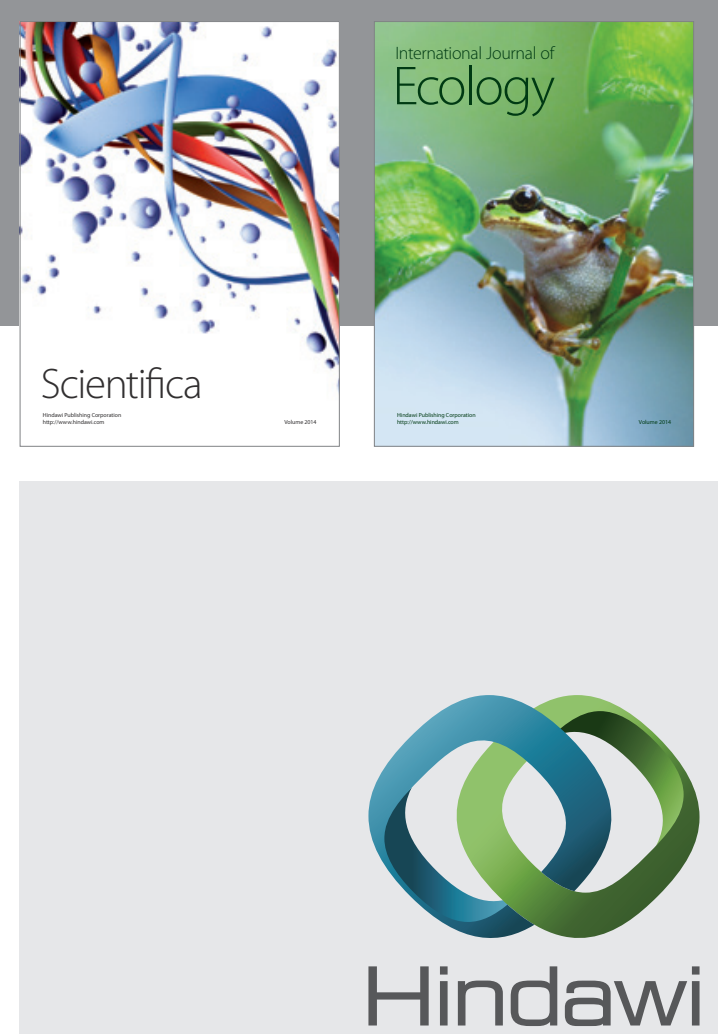

Submit your manuscripts at http://www.hindawi.com
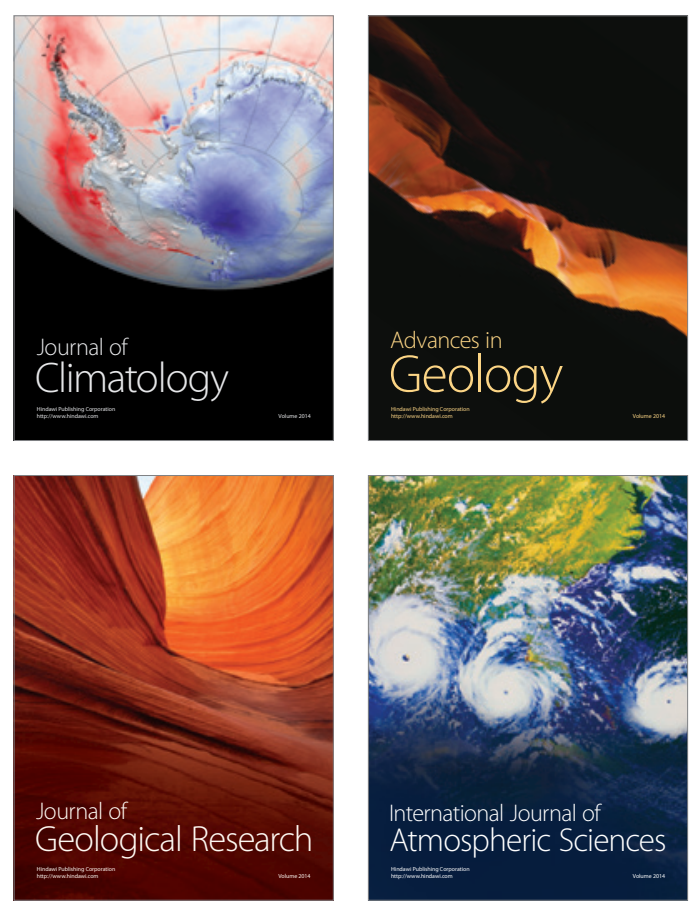
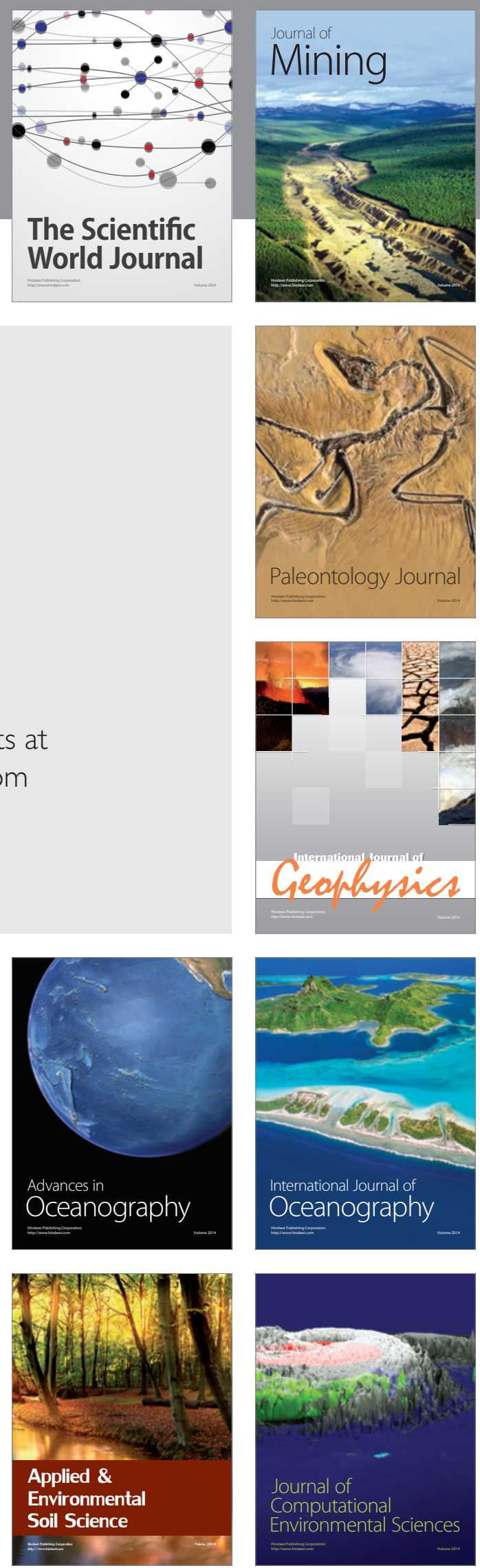